\title{
Sphingolipids: promising lipid-class molecules with potential applications for industry. A review
}

\author{
Krystian Miazek $^{(1,2)}$, Simon Lebecque ${ }^{(1,2)}$, Malik Hamaidia ${ }^{(1,2,3)}$, Aman Paul ${ }^{(1,2)}$, \\ Sabine Danthine ${ }^{(2)}$, Luc Willems ${ }^{(2,3)}$, Michel Frederich ${ }^{(4)}$, Edwin De Pauw ${ }^{(5)}$, \\ Magali Deleu ${ }^{(2)}$, Aurore Richel ${ }^{(2)}$, Dorothée Goffin ${ }^{(2)}$
}

\author{
(1) University of Liège - Gembloux Agro-Bio Tech. TERRA. AgricultureIsLife. Passage des Déportés, 2. BE-5030 Gembloux \\ (Belgium).E-mail: kmiazek@ulg.ac.be \\ (2) University of Liège - Gembloux Agro-Bio Tech. Agrobiochem. Passage des Déportés, 2. BE-5030 Gembloux (Belgium). \\ (3) University of Liège. Molecular and cellular epigenetics. GIGA. Avenue de l'Hôpital, 1. BE-4000 Sart-Tilman (Belgium). \\ (4) University of Liège. CIRM. Avenue de l'Hôpital, 1. BE-4000 Sart-Tilman (Belgium). \\ (5) University of Liège. Mass Spectrometry Laboratory. Allée de la Chimie, 3. BE-4000 Liège (Belgium).
}

Received on March 31, 2015; accepted on May 24, 2016.

Introduction. Sphingolipids are a group of lipid molecules, the focus on which has been gradually increasing during recent years. This review presents sphingolipids, as valuable compounds with a high potential for industry.

Literature. Structures of sphingolipids are described and their natural sources are presented. Different methods for extraction, purification and structural characterization of sphingolipids are evaluated. Activity of sphingolipids towards various microorganisms is discussed and methods for chemical modifications of natural sphingolipids to obtain novel properties are depicted. Finally, applications for implementing sphingolipid molecules in food, cosmetic, pharmaceutical or medical industry are proposed.

Conclusions. Sphingolipids are molecules of high impact and their importance will inevitably increase in the future.

Keywords. Sphingolipids, chemical structure, extraction, analysis, industrial uses.

Sphingolipides : des molécules lipidiques à haut potentiel de valorisation présentant de nombreuses applications industrielles (synthèse bibliographique)

Introduction. Les sphingolipides sont un groupe de molécules lipidiques qui suscitent un intérêt croissant ces dernières années. Cette revue présente les sphingolipides comme des composés à haute valeur ajoutée avec un potentiel pour leur application en industrie.

Littérature. Les structures des sphingolipides sont décrites et leurs sources naturelles sont présentées. Différentes méthodes pour l'extraction, la purification et la caractérisation des structures des sphingolipides sont évaluées. L'activité des sphingolipides envers différents micro-organismes est discutée et les méthodes de modification chimique des sphingolipides naturelles pour obtenir de nouvelles propriétés sont présentées. Finalement, des applications de molécules de sphingolipides dans les produits alimentaires, les cosmétiques, l'industrie pharmaceutique ou l'industrie médicale sont proposées.

Conclusions. Les sphingolipides sont des molécules à haut impact et leur importance augmentera inévitablement à l'avenir. Mots-clés. Sphingolipide, structure, extraction, analyse, usage industriel.

\section{INTRODUCTION}

Sphingolipids are a class of lipid molecules that possess diverse structures, from simple sphingoid bases to complex gangliosides. These molecules can be found in Eukaryotic cells, where sphingolipid synthesis occurs in endoplasmic reticulum (ER) and in the Golgi apparatus (Tidhar et al., 2013), although the occurrence of sphingolipids in some representatives of Prokaryota has also been reported (Naka et al., 2003). Sphingolipids perform structural functions in cells, as components of membranes or carry out signaling functions in processes, such as apoptosis (Tirodkar et al., 2012), cell growth (Spiegel et al., 1996) and cell differentiation (Bieberich, 2011) or a response to metal toxicity (Lee et al., 2012a), heat stress (Skrzypek 
et al., 1999), microbial (Heung et al., 2006) and viral (Schneider-Schaulies et al., 2013) infections.

High diversity of sphingolipids in terms of structure and biochemical functions, renders these molecules promising candidates for industrial application. In this review, different aspects of sphingolipids, ranging from structural characterization to natural sources and extraction methods, are discussed. Moreover, natural as well as chemical derivatives modified from natural sphingolipids are evaluated, in terms of their possible applications for various branches of industry.

\section{SPHINGOLIPIDS: STRUCTURAL DESCRIPTION}

Sphingolipid structure can differ considerably between types, but share a common long chain base (LCB); its structural core. Long chain (sphingoid) bases (Figure 1) are aliphatic amino alcohols that contain a long hydrocarbon tail, with hydroxyl groups at $\mathrm{C} 1$ and C3 and an amine group at C2 (Lynch et al., 2004). Although a basic sphingoid form is sphinganine that contains 18 carbon atoms, various LCBs in terms of desaturation, hydroxylation, methylation and carbon atoms occur in nature. For example, LCBs can exhibit double bonds at C4, C8, C10 (Tanaka et al., 1998) and even C5 and C12 (Poumale Poumale et al., 2011), C9 (El-Amraoui et al., 2013), C11 (Dongfack et al., 2012), C13 (Rho \& Kim, 2005) or C16 (Maia et al., 2010). Hydroxyl groups can be found at C4 (Bibel et al., 1992), C6 (Ramírez et al., 2008) or C13 and C14 (El-Amraoui et al., 2013), methyl group at C9 (Rho et al., 2005) and carbon atoms range from $\mathrm{C} 12$ to $\mathrm{C} 28$ (Maula et al., 2012).

If the amine group of a sphingoid base is $N$-acylated with a fatty acid moiety, a ceramide molecule is formed (Figure 2). Fatty acids in ceramide structures comprise from 12 to 34 carbon atoms (O'Brien et al., 1964; Wertz et al., 1983; Watanabe et al., 2011) and are usually saturated, rarely with unsaturated (double) bond. Additionally, fatty acids can contain a hydroxyl group at C2 (Maia et al., 2010) or C3 (Figure 2A) (Dongfack et al., 2012) and even a methyl group at C15 (Figure 2B) (Tanaka et al., 1998), although fatty acids with a terminal $(\omega)$ hydroxyl group, esterified with linoleic acid (Wertz et al., 1983), can also occur
(Figure 2C). Also groups, such as phosphocholine (Figure 2D) (Martínez-Beamonte et al., 2013) or phosphoinositol (Khotimchenko et al., 2004), are linked via phosphodiester bond to hydroxyl group of $\mathrm{C} 1$ in sphingoid base (Lynch et al., 2004). The most structurally complex class of sphingolipids are glycosphingolipids, in which a hydroxyl group at $\mathrm{C} 1$ of ceramide sphingoid base forms an $O$-linkage with sugar moieties (Figure 3).

Monoglycosylceramides, the simplest representatives of glycosphingolipids, are formed when glucose or galactose is bound with ceramide via a $\beta-1,1$ linkage to form glucosylceramide or galactosylceramide, respectively. Such monoglycosylceramides, called cerebrosides, can be subjected to further modifications. Galactosylceramides can undergo sulfation to form sulfatide (Figure 3A) (Jeon et al., 2008), containing sulfuric ester at $\mathrm{C} 3$ of galactose moiety. On the other hand, glucosylceramide can serve as a precursor for synthesis of lactosylceramides, oligoglycosphingolipids and gangliosides. When galactose is combined via a $\beta-1,4$ glycosidic linkage with glucose in a cerebroside, a lactosylceramide is formed, also found in a sulfated form (Sugita et al., 1974). An interesting example of glycosphingolipids is glycosyl-inositol-phosphoryl ceramide, in which inositol is coupled at C2 or C6 with mannose (Figure 3B), or at $\mathrm{C} 2$ with $N$-glucosamine $(\mathrm{GlcN})$ or $N$-acetylglucosamine (GlcNAc). Additional mannose, galactose, xylose and/or fucose moieties can also be found in glycosyl-inositol-phosphoryl ceramides (Buré et al., 2014).

Oligoglycosphingolipids contain oligosaccharide chains where glucose, covalently bonded to ceramide, is further extended with other carbohydrate residues, such as galactose, mannose, $N$-acetylglucosamine and/ or $N$-acetylgalactosamine (GalNAc). These residues are bonded to each other via various $(\beta-1,4, \beta-1,3, \beta-1,2$, $\alpha-1,4, \alpha-1,3)$ linkages to yield oligosaccharide chains, possessing diverse unit sequences (Haynes et al., 2009). For instance, globotriaosylceramide $\left(\mathrm{Gb}_{3}\right)$ contains galactose, connected via an $\alpha-1,4$ bond to a galactose, in a lactosyl unit. Further, when $N$-acetylgalactosamine is attached via a $\beta-1,3$ linkage to terminal galactose in $\mathrm{Gb}_{3}$ glycosyl sequence, globosides $(\mathrm{Gb})$ are formed. Also penta-, hexa- and hepta-glycosylceramides can be found, with 2 to 4 units of galactose, situated between $\mathrm{N}$-acetylgalactosamine and lactosyl units (Angstrom

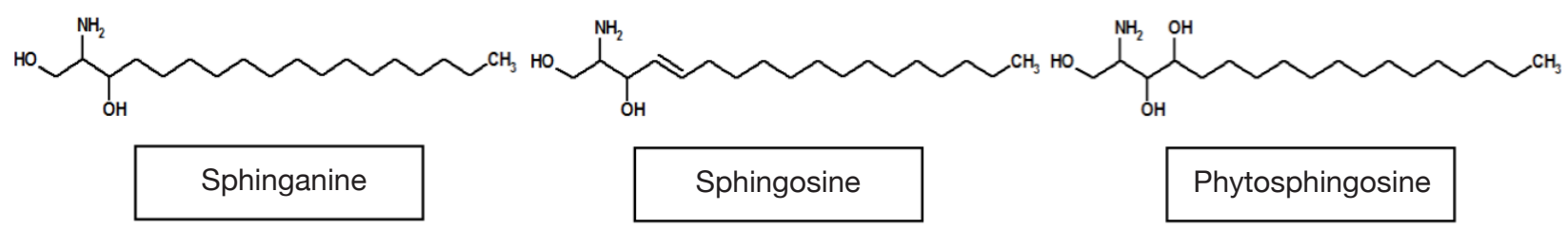

Figure 1. Exemplary structures of different sphingoid bases - Exemple de structures de différentes bases sphingoïdes. 
<smiles>CCCCCCC=CCCCCCCCCC(O)C(O)C(CO)NC(=O)C(O)C(O)CCCCCCCCCCCCCCCCCCCCCCC</smiles>

A

Ceramide

(Dongfack et al., 2012)

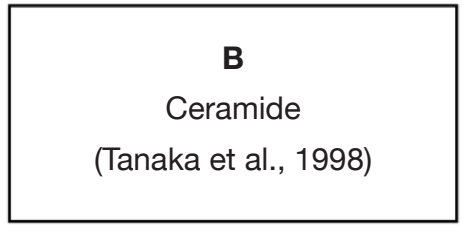<smiles>CCCCCCC/C=C/C=C/CC/C=C/C(O)C(CO)NC(=O)C(O)/C=C/CCCCCCCCCCC(C)CCC</smiles>

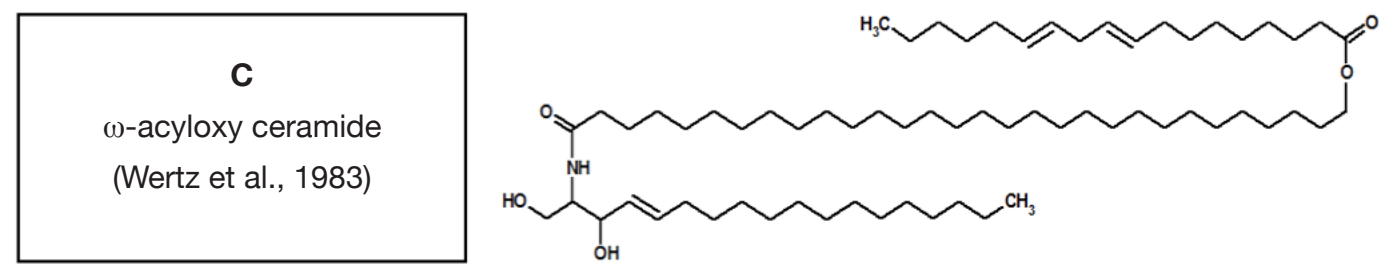<smiles>CCCCCCCCCCCC/C=C/C(O)C(COP(=O)(O)OCC[N+](C)(C)C)NC(=O)CCCCCCCCCCCCCCC</smiles>

D

Sphingomyelin

(Martinez-Beamonte et al., 2013)

Figure 2. Exemplary structures of different ceramides $(\mathbf{A}-\mathbf{C})$ and sphingomyelin $(\mathbf{D})-$ Exemples de structures de différents céramides $(\boldsymbol{A}-\boldsymbol{C})$ et sphingomyéline $(\boldsymbol{D})$.

et al., 1981). Interestingly, globosides were also reported in an elongated form with galactose $(\alpha-1,4) N-$ acetylgalactosamine $(\beta-1,3)$ galactose sequence, linked via an $\alpha-1,4$ linkage to terminal $N$-acetylgalactosamine of globoside (Figure 3C) (Duk et al., 2007).

Gangliosides are oligoglycosphingolipids that contain sialic acid moieties and are called monosialogangliosides $\left(\mathrm{G}_{\mathrm{M}}\right)$, disialogangliosides $\left(\mathrm{G}_{\mathrm{D}}\right)$, trisialogangliosides $\left(\mathrm{G}_{\mathrm{T}}\right)$ or tetrasialogangliosides $\left(\mathrm{G}_{\mathrm{Q}}\right)$, depending on the number of sialic acid unit, 1 to 4 respectively. What is more, gangliosides range from lactose $\left(\mathrm{G}_{\mathrm{M} 3}\right)$ to galactose $(\beta-1,3) N-$ acetylgalactosamine $(\beta-1,4)$ lactose $\quad\left(\mathrm{G}_{\mathrm{Ml}}, \mathrm{G}_{\mathrm{D} 1}, \mathrm{G}_{\mathrm{T1}}\right.$, $\mathrm{G}_{\mathrm{Q} 1}$ ), in their core carbohydrate chain (Figure 3D) (Ando et al., 1979; Haynes et al., 2009). Terminal galactose can be also sulfated at C3 (Figure 3E) (Tadano-Aritomi et al., 1998). Sialic acid is an $N-$ acetylneuraminic acid (NeuAc, Neu5Ac), linked via an $\alpha-2,3$ glycosidic bond to galactose in the carbohydrate structure, but can also be linked via an $\alpha-2,8$ glycosidic bond to another $N$-acetylneuraminic acid unit. Also,
$N$-glycolylneuraminic acid (NeuGc, Neu5Gc), a derivative of sialic acid, can be linked to galactose via an $\alpha-2,3$ glycosidic bond (Figure 3E) (Tadano-Aritomi et al., 1998) or to another $N$-glycolylneuraminic acid unit via an $\alpha-2,11$ linkage (Sisu et al., 2011). Moreover, $N$-glycolylneuraminic acid can be coupled with $N$-acetylgalactosamine via $\alpha-2,3$ and $\alpha-2,6$ bonds (Figure 3F) (Smirnova et al., 1988). Some varieties, such as monomethylated sialic acid linked via an $\alpha-2,6$ linkage to glucose (Yamada et al., 2008), fucose-containing monosialo-gangliosides (Kisa et al., 2006) and arabinose-containing gangliosides (Higuchi et al., 2006), were also reported. Additionally, an $O-$ acetylation at C9 (Daniotti et al., 2013), but also $O_{-}$ methylation (at C8, C9) or $O$-sulfation (at C8) of sialic acid unit can occur (Sisu et al., 2011). The presence of carboxyl group in a sialic acid unit renders gangliosides an acid nature, as in case of other sphingolipids containing phosphate or sulfate groups. As a contrary, neutral glycosphingolipids do not possess sialic acid moieties or any acidic groups. 


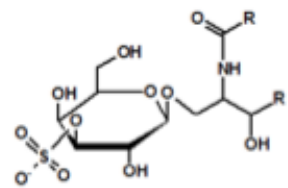

Sulfatide

(Jeon et al., 2008)
B

Glycosyl-inositol-ceramide

(Buré et al., 2014)
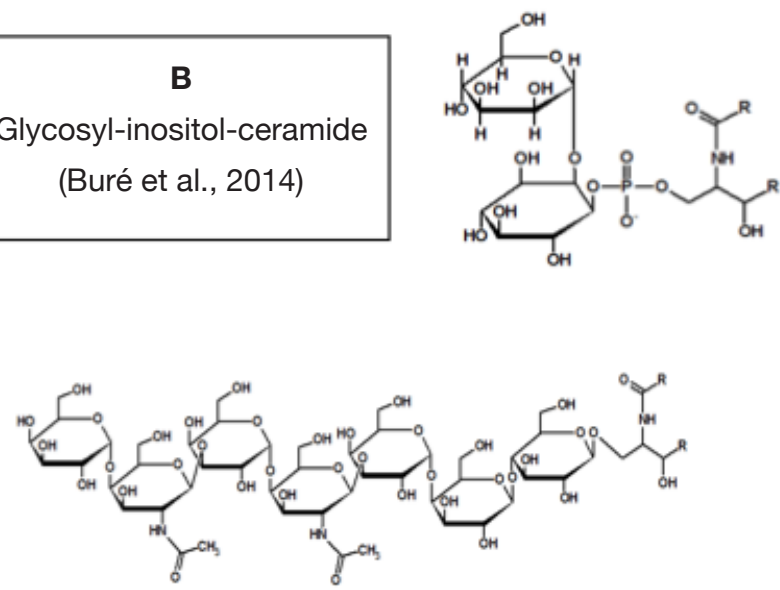

\section{C}

Elongated globoside

(Duk et al., 2007)

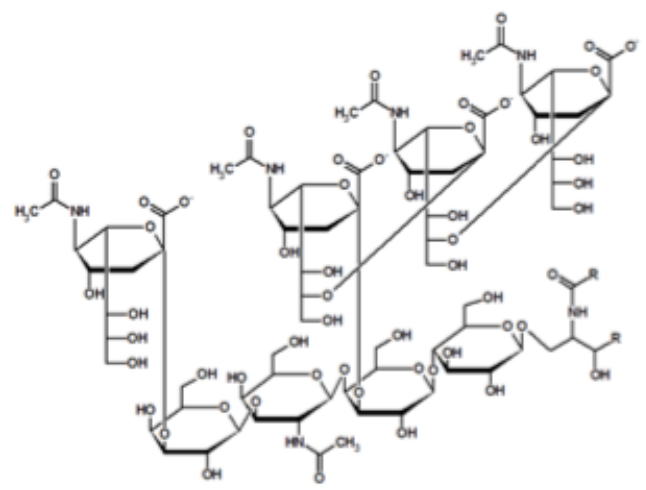

\section{D}

Tetrasialoganglioside

(Ando et al., 1979)

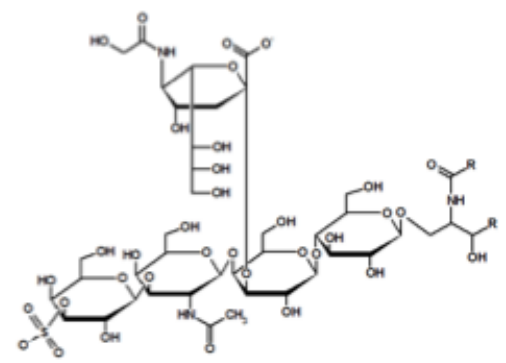

E

Sulfated monosialoganglioside (Tadano-Aritomi et al., 1998)

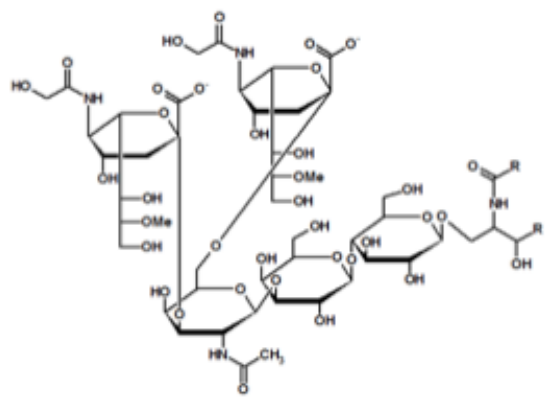

$\mathbf{F}$

Methylated disialoganglioside

(Smirnova et al., 1988)

Figure 3. Exemplary structures of different glycosphingolipids (A-F) - Exemples de structures de différents glycosphingolipides $(\boldsymbol{A}-\boldsymbol{F})$. 


\section{NATURAL SOURCES}

Sphingolipids are present in numerous specimens from kingdoms of Animalia, Plantae, Fungi, Protista and even Bacteria. Dairy products, meat (beef, veal, pork, chicken, turkey) products, eggs, soybeans and cereals are the major food source of sphingolipids (Vesper et al., 1999), although the presence of ceramides and gangliosides was also detected in wool fibers (Ramírez et al., 2008), fish gills (Bodennec et al., 2000), deer antler (Jhon et al., 1999) or fish brain tissue (Ando et al., 1979). A new sphingosine derivative, called haliscosamine, was isolated from Haliclona viscosa marine sponge (El-Amraoui et al., 2013). Starfish, such as Distolasterias nipon (Rho et al., 2005) or Asterias rubens (Smirnova et al., 1988), can be also a promising source of ceramides or gangliosides. New varieties of ceramides were identified and isolated during the analysis of extract from shrub Acnistus arborescens (Maia et al., 2010) and Ficus exasperate bark (Dongfack et al., 2012), although leaves are also an abundant source of sphingolipids (Markham et al., 2006; Watanabe et al., 2011). A huge variety of glycosyl-inositol-phosphoryl ceramides is available in fungi (Buré et al., 2014). An inositol-containing sphingolipid was also identified and isolated from red algae Gracilaria verrucosa (Khotimchenko et al., 2004). The presence of glycosphingolipids from marine cyanobacterium Moorea producens (Youssef et al., 2016), green microalgae Tetraselmis sp. (Arakaki et al., 2013) or diatom Skeletonema costatum (Zhao et al., 2013) and a new ceramide from dinoflagellate Coolia monotis (Tanaka et al., 1998) were also reported. Finally, phosphorylethanolamine ceramide, inositol-phosphoryl ceramide and mannose-phosphoryl ceramide were detected in Sphingobacterium spiritivorum (Naka et al., 2003). As sphingolipids are present in a huge variety of materials, selection of a proper source for sphingolipid production depends on natural availability of the source, composition and content of target sphingolipid molecules and extractive properties of material source. Such factors, when all combined together, should lead to achievable productivity of target sphingolipids, possibly on commercial scale, if properties and benefits of produced sphingolipids justify production cost and price of a final product.

\section{EXTRACTION METHODS}

Production of sphingolipids from various materials is usually accomplished by solvent extraction. A chloroform-methanol extraction (at a $\mathrm{v} / \mathrm{v}$ ratio of $2: 1,1: 2$ or $1: 1$ ), sometimes in the presence of $\mathrm{H}_{2} \mathrm{O}$ and with addition of $\mathrm{NaCl}$ (Groener et al., 2007) or
$\mathrm{KCl}$ (Jhon et al., 1999) to enhance phase formation, is the most common method used to release lipids from various materials. The use of methanol, ethanol and acetone (Ramírez et al., 2008), aqueous phenol (Gutierrez et al., 2007) or a mixture of butanol-ethyl acetate-hexane (Ogiso et al., 2014) has also been reported. On a laboratory scale, lipid extraction is usually carried out in tubes or Soxhlet apparatuses (Manirakiza et al., 2001). Recently, techniques such as Supercritical Fluid Extraction have also been successfully implemented. For instance, extraction of ceramide-containing lipid fraction from wool fibers was accomplished with the use of Supercritical $\mathrm{CO}_{2}$ Fluid Extraction. The presence of organic solvents, such as ethanol, methanol or acetone at concentration of $10 \%$, additionally improved lipid extraction process 2.5, 2.6 and 1.5 times, respectively. On the other hand, addition of $10 \%$ of diethyl ether decreased extraction yield by $66 \%$ (Ramírez et al., 2008). Lipids extracted from biological sources contain not only sphingolipids, but also other lipid-class molecules such as sterols and triglycerides (Gallier et al., 2010). Therefore, suitable techniques of lipid separation have to be implemented in order to produce and purify target sphingolipid molecules.

\section{SEPARATION AND ANALYSIS OF SPHINGOLIPIDS}

Extracted lipids constitute a mixture of numerous compounds, possessing different structures of neutral or acidic nature. In order to enable separation of sphingolipid fractions from mixtures of lipid-class molecules, techniques such as Solid Phase Extraction or Thin Layer Chromatography are usually implemented (Table 1).

Solid Phase Extraction (SFE) is an extraction method, where a solid phase and a liquid phase are used in order to isolate molecules or molecule fractions from mixtures. Solid phases can contain on their surfaces various groups, such as silanol, aminopropyl, octadecylsilane (C18), quarternary amine, etc. depending on the type of molecules, which are to be isolated. When a mixture is loaded on SFE, molecules from a mixture interact with surface groups of stationary phase and undesirable compounds are washed out with one type of solvent, while target molecules are eluted with the use of other types of solvents (Zwir-Ferenc et al., 2006). Lipids, loaded on aminopropyl-cartridge column and washed with a series of different solvents, were separated into different fractions: neutral lipids (triglyceride, cholesterol), free fatty acids, neutral phospholipids (phosphatidylcholine, phosphatidylethanolamine, sphingomyelin, cerebrosides) and acidic phospholipids (phosphatidylinositol, phosphatidylser- 
Table 1. Methods for separation and analysis of sphingolipids - Méthodes de séparation et d'analyse des sphingolipides.

\begin{tabular}{|c|c|c|c|}
\hline Compound & Separation & Detection & Reference \\
\hline \multicolumn{4}{|l|}{ Solid Phase Extraction (SPE) } \\
\hline Neutral sphingolipids & $\begin{array}{l}\text { Ion-exchange cartridges, with an } \\
\text { eluent } \mathrm{CHCl}_{3}-\mathrm{MeOH}-\text { Water }\end{array}$ & - & Kato et al., 2008 \\
\hline $\begin{array}{l}\text { Acidic sphingolipids } \\
\text { (gangliosides) }\end{array}$ & $\begin{array}{l}\text { Ion-exchange cartridges, with an } \\
\text { eluent } \mathrm{CHCl}_{3}-\mathrm{MeOH}-\mathrm{NH}_{4} \mathrm{OAc}\end{array}$ & - & Kato et al., 2008 \\
\hline Neutral glycosphingolipids & $\begin{array}{l}\text { Silica gel column, with an eluent } \\
\mathrm{CHCl}_{3}-\mathrm{MeOH}-\mathrm{H}_{2} \mathrm{O}\end{array}$ & - & Aoki et al., 2004 \\
\hline Inositol phosphoceramide & $\begin{array}{l}\text { Silica gel column, with an eluent } \\
\mathrm{CHCl}_{3}-\mathrm{MeOH}\end{array}$ & & $\begin{array}{l}\text { Khotimchenko et al., } \\
2004\end{array}$ \\
\hline Neutral glycosphingolipids & $\begin{array}{l}\text { Aminopropyl cartridges, with an } \\
\text { eluent Acetone-Methanol }\end{array}$ & - & \\
\hline Sphingomyelin & $\begin{array}{l}\text { Aminopropyl cartridges, with an } \\
\text { eluent } \mathrm{CHCl}_{3}-\mathrm{MeOH}\end{array}$ & - & Bodennec et al., 2000 \\
\hline $\begin{array}{l}\text { Acidic sphingolipids } \\
\text { (sphingosine phosphate, } \\
\text { caramide phosphate, } \\
\text { sulfatides) }\end{array}$ & $\begin{array}{l}\text { Aminopropyl cartridges, with an } \\
\text { eluent } \mathrm{CHCl}_{3}-\mathrm{MeOH}-\mathrm{NH}_{4} \mathrm{OAc}\end{array}$ & - & \\
\hline
\end{tabular}

\begin{tabular}{|c|c|c|c|}
\hline \multicolumn{4}{|c|}{ Thin Layer Chromatography (TLC) } \\
\hline Sphingoid bases & $\begin{array}{l}\text { Silica plates, with an eluent } \mathrm{CHCl}_{3}- \\
\mathrm{MeOH}-\mathrm{NH}_{4} \mathrm{OH}\end{array}$ & $\begin{array}{l}\text { Detection at UV } 366 \mathrm{~nm} \text {, } \\
\text { after primuline staining }\end{array}$ & Hidaka et al., 2012 \\
\hline Gangliosides & $\begin{array}{l}\text { Silica plates, with an eluent } \mathrm{CHCl}_{3}- \\
\mathrm{MeOH}-\mathrm{NH}_{4} \mathrm{OH}\end{array}$ & $\begin{array}{l}\text { Visualization, after } \\
\text { orcinol or resorcinol } \\
\text { staining }\end{array}$ & Jhon et al., 1999 \\
\hline Glycosphingolipids & $\begin{array}{l}\text { Silica plates, with an eluent } \mathrm{CHCl}_{3}- \\
\mathrm{MeOH} \text {-aqueous } \mathrm{KCl}\end{array}$ & $\begin{array}{l}\text { Visualization, after } \\
\text { resorcinol staining }\end{array}$ & Kato et al., 2008 \\
\hline Neutral sphingolipids & $\begin{array}{l}\text { Silica plates, with an eluent } \mathrm{CHCl}_{3}- \\
\mathrm{MeOH}-\text { Water }\end{array}$ & $\begin{array}{l}\text { Visualization, after iodine } \\
\text { vapour staining }\end{array}$ & Shiraishi et al., 1985 \\
\hline Fatty acid methyl esters & $\begin{array}{l}\text { Silica gel, with an eluent Hexane- } \\
\text { Diethyl ether }\end{array}$ & $\begin{array}{l}\text { Visualization, after bro- } \\
\text { mothymol blue staining }\end{array}$ & Tao et al., 1973 \\
\hline Phosphosphingolipids & $\begin{array}{l}\text { Silica gel, with an eluent } \mathrm{CHCl}_{3}- \\
\text { MeOH-Ammonia }\end{array}$ & $\begin{array}{l}\text { Visualization, after } \\
\text { molybdenum blue reagent }\end{array}$ & Bodennec et al., 2000 \\
\hline \multicolumn{4}{|c|}{ High Performance Liquid Chromatography - Reversed Phase (HPLC-RP) } \\
\hline Glucosylceramides & $\begin{array}{l}\text { Reversed phase column, with an } \\
\text { isocratic elution Methanol-Water }\end{array}$ & Detection at UV $210 \mathrm{~nm}$ & Imai et al., 2012 \\
\hline $\begin{array}{l}\text { Sphingoid bases (as } \\
\text { o-phthaldialdehyde } \\
\text { derivatives) }\end{array}$ & $\begin{array}{l}\text { Reversed phase column, with an } \\
\text { elution phase } \mathrm{MeOH}-\mathrm{H}_{2} \mathrm{O}- \\
\mathrm{N}\left(\mathrm{CH}_{2} \mathrm{CH}_{3}\right)_{3}\end{array}$ & $\begin{array}{l}\text { Detection of emission at } \\
455 \mathrm{~nm} \text {, after fluorescence } \\
\text { excitation at } 340 \mathrm{~nm}\end{array}$ & Lee et al., 2012 \\
\hline $\begin{array}{l}\text { Sphingoid bases (as } \\
\text { o-phthaldialdehyde } \\
\text { derivatives) }\end{array}$ & $\begin{array}{l}\text { Reversed phase chromatography, with } \\
\text { an eluent composed of } \mathrm{K}_{3} \mathrm{PO}_{4} \text { and/or } \\
\text { Methanol on gradient mode }\end{array}$ & $\begin{array}{l}\text { Detection of emission at } \\
455 \mathrm{~nm} \text {, after fluorescence } \\
\text { excitation at } 340 \mathrm{~nm}\end{array}$ & Markham et al., 2006 \\
\hline $\begin{array}{l}\text { Sphingoid bases (as } \\
\text { fluoro-nitrobenzofurazan } \\
\text { derivatives) }\end{array}$ & $\begin{array}{l}\text { Reversed phase chromatography, with } \\
\text { an eluent composed of } \mathrm{H}_{2} \mathrm{O}-\mathrm{HCOOH} \\
\text { and } \mathrm{MeOH}-\mathrm{CH}_{3} \mathrm{CN} \text { on gradient mode }\end{array}$ & $\begin{array}{l}\text { Detection of emission at } \\
530 \mathrm{~nm} \text {, after fluorescence } \\
\text { excitation at } 470 \mathrm{~nm}\end{array}$ & Ishikawa et al., 2014 \\
\hline $\begin{array}{l}\text { Sphingoid bases (as biphe- } \\
\text { nylcarbonyl derivatives) }\end{array}$ & $\begin{array}{l}\text { Reversed phase column with an iso- } \\
\text { cratic elution THF-Methanol-Water }\end{array}$ & Detection at UV $280 \mathrm{~nm}$ & Jungalwala et al., 1983 \\
\hline $\begin{array}{l}\text { Sialic acid (as diamino- } \\
\text { methylenedioxybenzene } \\
\text { derivatives) }\end{array}$ & $\begin{array}{l}\text { Reversed phase chromatography, with } \\
\text { an isocratic elution } \mathrm{CH}_{3} \mathrm{CN}-\mathrm{MeOH}- \\
\text { Water }\end{array}$ & $\begin{array}{l}\text { Detection of emission at } \\
448 \mathrm{~nm} \text {, after fluorescence } \\
\text { excitation at } 373 \mathrm{~nm}\end{array}$ & Sonnenburg et al., 2002 \\
\hline
\end{tabular}


Table 1 (continued). Methods for separation and analysis of sphingolipids - Méthodes de séparation et d'analyse des sphingolipides.

\begin{tabular}{|c|c|c|c|}
\hline Compound & Separation & Detection & Reference \\
\hline \multicolumn{4}{|c|}{ High Performance Liquid Chromatography - Ion Exchange (HPLC-IE) } \\
\hline Gangliosides & $\begin{array}{l}\text { Separation of gangliosides on a } \\
\text { column possessing ion exchange } \\
\text { properties, with increasing salt } \\
\text { gradient as an eluent }\end{array}$ & Detection at UV $210 \mathrm{~nm}$ & Whalen et al., 1986 \\
\hline $\begin{array}{l}\text { Sialic acid and hexoses } \\
\text { (from gangliosides) }\end{array}$ & $\begin{array}{l}\text { Ion exchange column, with } \mathrm{NaOH}- \\
\text { NaOAc as an eluent }\end{array}$ & $\begin{array}{l}\text { Pulsed Amperometric } \\
\text { Detector (PAD) }\end{array}$ & Jhon et al., 1999 \\
\hline \multicolumn{4}{|c|}{ Gas Chromatography (GC) } \\
\hline $\begin{array}{l}\text { Sphingoid bases (as fatty } \\
\text { aldehydes), sphingoids } \\
\text { bases (as dimethylace- } \\
\text { tals), inositol (as inositol } \\
\text { hexaacetate), fatty acids } \\
\text { (as methyl esters), sugars } \\
\text { (as partially methylated } \\
\text { alditol acetates), } \\
\text { 2-hydroxy fatty acids } \\
\text { (as methoxy fatty acid } \\
\text { methyl esters), sialic } \\
\text { acids (as TMS deriva- } \\
\text { tives), 2-hydroxy fatty } \\
\text { acids (as acetoxy fatty } \\
\text { acid methyl esters), sialic } \\
\text { acids (as heptafluorobu- } \\
\text { tyrate derivatives) }\end{array}$ & $\begin{array}{l}\text { Capillary column with helium as } \\
\text { carrier gas. Temperature of column } \\
\text { during analysis: isocratic }(210- \\
\left.220^{\circ} \mathrm{C}\right) \text { or gradient }\left(50-320^{\circ} \mathrm{C}\right)\end{array}$ & $\begin{array}{l}\text { Flame Ionization Detector } \\
\text { (FID) at } 240{ }^{\circ} \mathrm{C} \text { or } \\
\text { Connected to } \mathrm{MS}\end{array}$ & $\begin{array}{l}\text { O’Brien et al., 1964; } \\
\text { Tao et al., 1973; Johnson } \\
\text { et al., 1992; Jhon et al., } \\
\text { 1999; Zanetta et al., } \\
\text { 2001; Aoki et al., 2004; } \\
\text { Khotimchenko et al., } \\
\text { 2004; Cacas et al., 2012 }\end{array}$ \\
\hline \multicolumn{4}{|l|}{ Mass Spectrometry (MS) } \\
\hline Sphingoid base & $\mathrm{LC}$ & ESI-MS/MS & Ishikawa et al., 2014 \\
\hline Sphingomyelin & $\mathrm{LC}$ & ESI-MS/MS & Zhou et al., 2012 \\
\hline Ceramide & $\mathrm{LC}$ & ESI-MS/MS & Lee et al., 2003 \\
\hline Sialic acid & $\mathrm{LC}$ & ESI-MS/MS & Sonnenburg et al., 2002 \\
\hline Glycosylceramide & $\mathrm{LC}$ & ESI-MS/MS & Zhao et al., 2013 \\
\hline Sulfatide & $\mathrm{LC}$ & ESI-MS/MS & Shaner et al., 2009 \\
\hline Glycosylceramide & LC, TLC & $\begin{array}{l}\text { MALDI-TOF/TOF, ESI- } \\
\text { MS/MS }\end{array}$ & Arakaki et al., 2013 \\
\hline Globotriaosylceramide & $\mathrm{LC}$ & APCI-MS/MS & Farwanah et al., 2009 \\
\hline Gangliosides & - & MALDI-TOF/TOF & Chan et al., 2009 \\
\hline Fatty acids & GC & EI & Devle et al., 2011 \\
\hline Inositol, sugars & GC & FAB & Naka et al., 2003 \\
\hline Sphingoid base & GC & FAB-MS/MS & Rho et al., 2006 \\
\hline
\end{tabular}

ine, phosphatidic acid) (Kim et al., 1990). Similarly, aminopropyl- bonded silica gel column chromatography was used to separate lipid extract into non-polar lipids (cholesterol, cholesterol esters, glycerides), free fatty acids, neutral polar lipids (phosphatidylethanolamine, phosphatidylcholine, sphingomyelin, galactosylceramide, lactosylceramide) and polar acidic lipids (phosphatidylglycerol, phosphatidylinositol, phospha- tidylserine, gangliosides) (Alvarez et al., 1992). In another study, lipid extract from fungal mycelia was initially fractionized on ion exchange column to obtain neutral glycosphingolipids-containing fraction, which was further purified on silica gel column (Aoki et al., 2004). For elution of acidic sphingolipids, a mobile phase containing a salt solution ( $\mathrm{NaOAc}, \mathrm{NH}_{4} \mathrm{OAc}$ ), at an appropriate $\mathrm{pH}$ to maintain separated sphingolipids 
in their ionic form, is used. Eluted acidic fractions can be composed of a single sphingolipid compound or can consist of sphingolipids, belonging to the same class but differing in structure. For example, a lipid extract from rat brain tissue was separated using ion exchange cartridges into two fractions: neutral lipids and gangliosides-containing acidic fraction, as neutral lipids were washed out firstly, followed by gangliosides. What is more, various gangliosides were also successfully separated in this process (Kato et al., 2008). SPE of the lipid extract from fish gills on aminopropyl cartridges, with the use of different mobile phase composition, resulted in a complex separation of lipid mixture into various neutral sphingolipid fractions (ceramides, neutral glycosphingolipids or sphingomyelin) and one acidic fraction (sphingosine phosphates, ceramide phosphates and sulfatides) (Bodennec et al., 2000).

Thin Layer Chromatography (TLC) is a technique, where compounds from the mixture are separated on a thin layer of stationary phase, which is usually the silica gel (Fuchs et al., 2011). TLC can be used for further purification of sphingolipid fractions into single compounds, as well as for evaluating the purity of sphingolipid fractions obtained upon Solid Phase Extraction. Reagents, such as orcinol (Jhon et al., 1999) or resorcinol solutions (Jhon et al., 1999; Kato et al., 2008), iodine vapor (Shiraishi et al., 1985), primuline (Hidaka et al., 2012), bromothymol blue (Tao et al., 1973) or molybdenum blue (Bodennec et al., 2000), can be used to detect sphingolipid fractions, which can be scraped from the silica plate after visualization. Thin Layer Chromatography can also be used for detection of specific single sphingolipids, when known standard compounds are run through TLC gel plate and are visualized with a reagent, adjusted for a specific sphingolipid. Techniques, such as SPE and TLC, enable initial separation of sphingolipids into fractions of the same class or even purification of single compounds, but are usually not sufficient for structural characterization of sphingolipids, especially if sphingolipids of unknown structure are to be characterized. Therefore, it is necessary to apply advanced techniques (Table 1) for complex identification of their structure.

High Performance Liquid Chromatography (HPLC) can be used for separation of sphingolipid mixtures. For example, single gangliosides were separated, according to their number of sialic acid residues, from the mixture of glycolipids applied on an ion-exchange column, coupled with a UV detector (Whalen et al., 1986). On the other hand, glucosylceramides were also separated on Reversed Phase (RP) HPLC, due to their hydrophobic interactions. Moreover, RP-HPLC enabled separation of glucosylceramides, possessing sphingoid bases in cis or trans configuration (Imai et al., 2012). However, most often, HPLC and GC are harnessed for identification of specific parts in sphingolipid structure. A sphingolipid molecule possesses a sphingoid base, but can also contain fatty acid, sugar and sialic acid moieties. Therefore, two approaches are used for sphingolipid characterization with the use of HPLC (Haynes et al., 2009) and GC (Sisu et al., 2011). In the first approach, a single compound purified during SPE, TLC or HPLC, is subjected to hydrolysis and selected parts are further analyzed by HPLC or GC. In the second approach, various compounds in the fraction are simultaneously hydrolyzed and selected parts of one type (fatty acids, sphingoid bases, etc.) from different compounds are analyzed by HPLC or GC, leading to characterization of the overall profile of selected structural parts, in the mixture of different compounds. In order to analyze selected structural parts, sphingolipid molecules are hydrolyzed via a variety of chemical reactions.

Hydrolysis of fatty acids from sphingolipids can be achieved by cleavage of the amide bond, with the use of methanolic solution of $\mathrm{HCl}$ (Hidaka et al., 2012), $\mathrm{BF}_{3}$ (Devle et al., 2011) or $\mathrm{NaOH}$ (Groener et al., 2007), and further with the support of microwaves (Groener et al., 2007; Devle et al., 2011). Another method to release fatty acids from sphingolipids, is the enzymatic hydrolysis via sphingolipid ceramide $\mathrm{N}$-deacylase (SCDase) action that breaks the $\mathrm{N}$-acyl linkage (Lee et al., 2012b). Long chain sphingoid bases (LCB) can be obtained due to $\mathrm{HCl}$ methanolysis (Goto et al., 2012) or alkaline hydrolysis with $\mathrm{Ba}(\mathrm{OH})_{2}$ and dioxane (Markham et al., 2006). Sugar and sialic acid moieties can be released from gangliosides, as a result of trifluoroacetic acid (TFA) treatment (Jhon et al., 1999). Also, enzymatic hydrolysis of glycosphingolipids, with ceramide glycanase (Zhou et al., 1989) and sialidase (Rodriguez et al., 1996), can lead to the release of sugar and sialic acid moieties, respectively. Sialic acids and sugars can be analyzed by High Performance Anion Exchange Chromatography (HPAEC), possessing ion exchange column and Pulsed Amperometric Detector (PAD) (Jhon et al., 1999). However, in order to be successfully analyzed by HPLC or GC, structural parts of sphingolipids usually have to undergo derivatization (Table 1). Sphingoid bases are often combined with biphenylcarbonyl chloride (Jungalwala et al., 1983), $O$-phthaldialdehyde (Markham et al., 2006; Lee et al., 2012b) or fluoronitrobenzofurazan (Ishikawa et al., 2014) in order to interact with stationary phase in Reversed-Phase HPLC. Also, sialic acid undergoes reaction with diamino-methylenedioxybenzene (Sonnenburg et al., 2002), before RP-HPLC characterization.

For Gas Chromatography analysis, it is necessary to convert structural parts of sphingolipids into their volatile derivatives. Fatty acids are converted to fatty acid methyl esters, during acid methanolysis of sphingolipids (Jhon et al., 1999; Aoki et al., 2004). 
Fatty acids or 2-hydroxy fatty acids can be also converted in iodomethane/dimethylacetamide $/ \mathrm{NaOH}$ solution to fatty acid methyl esters and 2-methoxy fatty acid methyl esters, respectively (Johnson et al., 1992). What is more, acetylation of hydroxy fatty acid methyl esters into acetoxy methyl esters, was also reported (O'Brien et al., 1964). Sphingoid bases can be trimethylsilylated into TMS ether derivatives, or both $N$-acetylated in methanol/acetic anhydride solution and trimethylsilylated to yield $N$-acetyl TMS ether derivatives (Carter et al., 1967). On the other hand, sphingoid bases are oxidized by sodium metaperiodate to fatty aldehydes (Cacas et al., 2012), followed by their conversion to dimethylacetals (Khotimchenko et al., 2004). Inositol, released from sphingolipids, undergoes acetylation to form an inositol hexaacetate (Khotimchenko et al., 2004). Glycosylceramides undergo complete $O$-methylation with iodomethane $\left(\mathrm{CH}_{3} \mathrm{I}\right) / \mathrm{NaOH} / \mathrm{DMSO}$ and further hydrolysis to release partially methylated sugar moieties (Sisu et al., 2011). Partially methylated sugars are reduced by sodium borohydride $\left(\mathrm{NaBH}_{4}\right)$ and undergo acetylation in acetic anhydride/pyridine solution to yield partially methylated alditol acetates (Aoki et al., 2004; Sisu et al., 2011). Sialic acid can be converted to TMS (Tao et al., 1973) or heptafluorobutyrate derivatives (Zanetta et al., 2001).

LC and GC are widely and commonly used for analysis of known sphingolipids, when retention times between standard and analyzed compounds are compared. However, these techniques alone are not sufficient for characterization of molecules possessing novel and unknown structure, for example from new sources or after chemical modifications. In such a case, Mass Spectrometry (MS) techniques are applied.

In Mass Spectrometry, analyzed sphingolipids are firstly ionized to charged molecules and subsequently measured, according to their mass to charge $(\mathrm{m} / \mathrm{z})$ ratios. The types of ion sources in MS (Table 1), such as Electron Ionization (EI), Fast Atom Bombardment (FAB), Electrospray Ionization (ESI), Matrix Assisted Laser Desorption/Ionization (MALDI) and Atmospheric Pressure Chemical Ionization (APCI), are used for characterization of fatty acids, sphingoid bases, ceramides, glycosylceramides and gangliosides (Farwanah et al., 2009; Haynes et al., 2009). Electron Ionization is a method, where compounds are ionized in the gas phase and hence their conversion (trimethylsilylation, permethylation) into volatile derivatives is required beforehand. Moreover, in this ionization method high energy is applied and a complete breakage of molecular ion into many fragments, often occurs. FAB, ESI, MALDI and APCI are "softer" methods, leading to a lower degree of fragmentation and analysis of larger charged molecules. ESI is a gentle ionization method that enables one to obtain a major parent ion, as well as major product ions and to identify a typical profile for sphingolipids (Lee et al., 2003; Markham et al., 2006; Zhou et al., 2012; Ishikawa et al., 2014). HPLC, coupled with tandem mass spectrometry (MS/MS), is a very common approach used for sphingolipidomic analyses. In a tandem mass spectrometry, two stages of mass analysis are applied for a selective fragmentation of particular ions (one $\mathrm{m} / \mathrm{z}$ value) from a mixture of ions. Sphingolipid molecules can be analyzed on the positive $\left[(\mathrm{M}+\mathrm{H})^{+}\right.$, $\left.(\mathrm{M}+\mathrm{Li})^{+},(\mathrm{M}+\mathrm{Na})^{+}\right]$or negative $\left[(\mathrm{M}-\mathrm{H})^{-},(\mathrm{M}+\mathrm{Cl})^{-}\right.$, $\left.(\mathrm{M}+\mathrm{HCOO})^{-}\right]$ion mode. Mass analyzers, such as Ion Trap, Quadrupole (Q) and Time of Flight (TOF), are harnessed for sphingolipid analysis (Bielawski et al., 2010). Popular types of tandem mass spectrometry are: ESI-triple quadrupole MS, ESI-Q-TOF MS, ESI-Q-Ion Trap MS, MALDI-TOF-TOF MS and APCI-Q-TOF MS (Chan et al., 2009; Farwanah et al., 2009; Shaner et al., 2009; Arakaki et al., 2013; Zhao et al., 2013). Gas chromatography is usually coupled with electron ionization (GC-EI) (Sisu et al., 2011) and liquid chromatography is combined with other types of mass spectrometry (Haynes et al., 2009).

In order to completely elucidate the structure of analyzed sphingolipids, the linkage configuration, the presence of double bonds, hydroxyl and other side moieties, need to be determined. Fragment ions of sphingolipid molecules, supported by chemical hydrolysis, derivatization or comparison with standard reference compounds, can lead to full elucidation of sphingolipid structure. If it is not achievable, techniques such as Fourier Transform Infrared Spectroscopy (FTIR) or NMR are applied.

In FTIR spectroscopy, different groups in sphingolipid structure, such as $\mathrm{OH}, \mathrm{C}=\mathrm{C}, \mathrm{C}-\mathrm{N}$ and (CO)-N, absorb different wavelengths of infrared radiation that are specific only for those structures, thereby providing information about chemical characteristics of analyzed sphingolipid molecules (Dongfack et al., 2012).

Nuclear Magnetic Resonance (NMR) is the most advanced technique that enables structural identification of molecules, based on different chemical shifts $(\delta)$ of observed nucleus, within an analyzed molecule (Fuchs et al., 2011). As sphingolipids are composed mainly of $\mathrm{C}$ and $\mathrm{H}$ atoms, ${ }^{1} \mathrm{H}$ NMR, ${ }^{13} \mathrm{C}$ NMR and (2D) NMR (COSY, HMBC) are harnessed to detect the presence of ${ }^{1} \mathrm{H}$ and ${ }^{13} \mathrm{C}$ isotopes and identify sphingolipids structure. Analysis of ${ }^{1} \mathrm{H},{ }^{13} \mathrm{C}$ NMR and (2D) NMR spectra enables estimation of carbon atoms, number and localization of double bonds, the presence of moieties (hydroxyl, methyl), but also configuration of double bonds (Rho et al., 2005; Maia et al., 2010). Sphingolipid analysis by NMR can be fulfilled for an intact molecule (Arakaki et al., 2013) or for a part of its structure, after hydrolysis (Tanaka et al., 1998) and derivatization (Iga 
et al., 2008). Usually, chromatography, MS, FTIR and NMR are used simultaneously for mutual support (Rho et al., 2005).

\section{INHIBITORY ACTIVITY OF NATURAL SPHINGOLIPIDS: POTENTIAL APPLICATIONS FOR INDUSTRY}

Sphingolipids, extracted and purified from natural sources, can express growth suppressing and antiadhesive activity against various microorganisms (Table 2).

Sphingolipids showed growth inhibitory activity against bacteria $\left(\mathrm{Gram}^{+}, \mathrm{Gram}^{-}\right)$, fungi or microalgae (Bibel et al., 1992; Tang et al., 2010; Poumale Poumale et al., 2011; Dongfack et al., 2012; Fischer et al., 2012; El-Amraoui et al., 2013; Murshid et al., 2016) and the rate of inhibition depends on sphingolipid structure, as well as on microbial strain tested. The inhibitory activity of sphingolipids towards microorganisms is suggested to be due to their ability to interact with microbial cell wall membranes, causing their perforation. As a result, the leakage of cellular content and consequently microbial death occurs. However, antimicrobial effect of sphingolipids can strictly depend on environmental conditions, including $\mathrm{pH}$ value and temperature or the presence of ions $\left(\mathrm{Ca}^{2+}\right)$ and organic compounds, such as fatty acids, proteins, surfactants or even other sphingolipids (Possemiers et al., 2005). Adhesion of pathogenic bacteria to intestine or gastric epithelial cells causes the occurrence of diarrhea, gastritis or gastric cancer. Gangliosides were reported to efficiently inhibit the adhesion of bacteria to these cells (Idota et al., 1995; Hata et al., 2004). The inhibitory effect of gangliosides is due to the presence of oligosaccharide residue and the rate of inhibition depends on the composition of oligosaccharide chain, as well as on microbial strains involved in adhesion process.

The ability of sphingolipids to suppress the development of bacteria and fungi, renders them to be potentially used as food supplements to improve the profile of intestine microflora (Kurek et al., 2013) or as cosmetic ingredients to prevent skin infection. Gut microbiota is a very diverse ecosystem and stress factors can lead to the development of pathogenic bacteria (Mroczynska et al., 2011). It was reported that gangliosides $\left(\mathrm{GM}_{3}, \mathrm{GD}_{3}, \mathrm{GM}_{1}\right)$ and sialic acid(Neu5Ac), within concentration ranges present in commercial infant formulas and human milk, were able to partially inhibit adhesion of pathogenic bacteria, involved in the occurrence of diarrhea in neonates (Salcedo et al., 2013). Due to structural and modulatory functions, sphingolipids are essential components of the skin and ceramide reduction is associated with the development of skin diseases (Kleuser et al., 2013). Ceramide- containing skin care products were reported to improve the treatment of eczema (Draelos, 2008). Sphingolipids could also become a replacement for antibiotics or other substances that possess insufficient activity towards new drug-tolerant pathogens (Sambanthamoorthy et al., 2014). Moreover, sphingolipids could serve as anti-biofilm agents and as components for medical and pharmaceutical products, where occurrence of harmful pathogenic microbiota is highly undesirable (Alasil et al., 2014). However, composition and concentration of sphingolipids present in commercial products must be always evaluated, in terms of their possible toxicity towards human skin and digestive system.

\section{CHEMICAL MODIFICATIONS OF NATURAL SPHINGOLIPIDS: NEW APPLICATIONS FOR INDUSTRY}

Natural sphingolipids, purified from biological samples, can undergo further chemical modifications, resulting in sphingolipid derivatives that possess new properties, interesting for cosmetic, pharmaceutical and medical applications. For example, sphingosine (4-sphingenine) can be coupled with phenethyl isothiocyanate to possess increased inhibitory activity towards human leukemia cell growth, when compared to sphingosine itself (Xu et al., 2000). A coupling of sphingosine with benzopentasulfane led to formation of ceramidebenzopolysulfane conjugate that possesses enhanced inhibitory activity against human breast cancer cells, in comparison to parent unsubstituted benzopolysulfane (Mahendran et al., 2015). Sphingosine can be also modified to alkynyl-sphingomyelin (Sandbhor et al., 2009), in a series of reactions that includes: sphingosine conversion into 2-azido-sphingosine, phosphorylation of 2-azido-sphingosine, with its amination by means of alkynylammonium head-group and final $N$-acylation with fatty acid to obtain alkyne-modified sphingomyelin. Alkyne-modified sphingomyelin retains the same interaction with cholesterol as a native sphingomyelin (Goretta et al., 2012) and if an ammonia group of alkyne-modified sphingomyelin is further coupled with a fluorophore, new molecular probes can be designed (Sandbhor et al., 2009). On the other hand, sphingomyelin, subjected to hydroxyl radicals generated during Fenton reaction, can be hydrolyzed at its $\mathrm{N}$-acyl linkage into sphingosylphosphorylcholine, with its further conversion into hydroxyl and ketone products. Oxidized sphingolipids may play an important role during development of clinical diseases (Melo et al., 2012). Treatment of various sphingolipids with hypochlorous acid $(\mathrm{HOCl})$, resulted in the formation of mono- and dichloramine- derivatives of sphingolipids, as well as a radical-related decomposition product: hexadecenal, possessing a wide spectrum of biologi- 
Table 2. Antimicrobial activity of sphingolipids - L'activité antimicrobienne des sphingolipides.

\begin{tabular}{llll}
\hline Sphingolipid & Inhibitory concentration & Strain & Reference
\end{tabular}

\section{Growth inhibition}

Sphinganine
$50 \%$ decrease at $0.78 \mu \mathrm{M} \cdot \mathrm{ml}^{-1}$ lipid

$50 \%$ decrease at $1.56 \mu \mathrm{M} \cdot \mathrm{ml}^{-1}$ lipid

$50 \%$ decrease at $0.78 \mu \mathrm{M} \cdot \mathrm{ml}^{-1}$ lipid

$50 \%$ decrease at $0.78 \mu \mathrm{M} \cdot \mathrm{ml}^{-1}$ lipid

$50 \%$ decrease at $\sim 2.5 \mu \mathrm{M} \cdot \mathrm{ml}^{-1}$ lipid

$50 \%$ decrease at $\sim 19 \mu \mathrm{M} \cdot \mathrm{ml}^{-1}$ lipid

No decrease at $6.25 \mu \mathrm{M} \cdot \mathrm{ml}^{-1}$ lipid

No decrease at $6.25 \mu \mathrm{M} \cdot \mathrm{ml}^{-1}$ lipid

$50 \%$ decrease at $\sim 1.2 \mu \mathrm{M} \cdot \mathrm{ml}^{-1}$ lipid $50 \%$ decrease at $0.78 \mu \mathrm{M} \cdot \mathrm{ml}^{-1}$ lipid

$\sim 50 \%$ decrease at $25-35 \mu \mathrm{M}$
Staphylococcus aureus

Streptococcus pyogenes

Propionibacterium acnes

Brevibacterium epidermidis

Micrococcus luteus

Bibel et al., 1992

Pseudomonas aeruginosa

Escherichia coli

Serratia marcescens

Candida ablicans

\begin{tabular}{ll}
\hline Sphingosine & $50 \%$ decrease at $0.78 \mu \mathrm{M} \cdot \mathrm{ml}^{-1}$ lipid \\
\hline Sphingosine & $\sim 50 \%$ decrease at $25-35 \mu \mathrm{M}$
\end{tabular}

\section{Escherichiacoli.}

Enterobacter aerogenes,

Clostridium perfringens,

Lactobacillus acidophilus,

Lactobacillus amylovorus,

Bifidobacterium longum,

Bifidobacterium bifidum

\begin{tabular}{|c|c|c|c|}
\hline Sphingosine & $\mathrm{MIC}_{>50}=7.8 \mu \mathrm{g} \cdot \mathrm{ml}^{-1}$ & Escherichia coli & \multirow{12}{*}{ Fischer et al., 2012} \\
\hline Phytosphingosine & $\mathrm{MIC}_{>50}=3.9 \mu \mathrm{g} \cdot \mathrm{ml}^{-1}$ & Escherichia coli & \\
\hline Sphinganine & $\mathrm{MIC}_{>50}=15.6 \mu \mathrm{g} \cdot \mathrm{ml}^{-1}$ & Escherichia coli & \\
\hline Sphingosine & $\mathrm{MIC}_{>50}=>500 \mu \mathrm{g} \cdot \mathrm{ml}^{-1}$ & Pseudomonas aeruginosa & \\
\hline Phytosphingosine & $\mathrm{MIC}_{>50}=>500 \mu \mathrm{g} \cdot \mathrm{ml}^{-1}$ & Pseudomonas aeruginosa & \\
\hline Sphinganine & $\mathrm{MIC}_{>50}=>500 \mu \mathrm{g} \cdot \mathrm{ml}^{-1}$ & Pseudomonas aeruginosa & \\
\hline Sphingosine & $\mathrm{MIC}_{>50}=1.3 \mu \mathrm{g} \cdot \mathrm{ml}^{-1}$ & Staphylococcus aureus & \\
\hline Phytosphingosine & $\mathrm{MIC}_{>50}=1.6 \mu \mathrm{g} \cdot \mathrm{ml}^{-1}$ & Staphylococcus aureus & \\
\hline Sphinganine & $\mathrm{MIC}_{>50}=1.3 \mu \mathrm{g} \cdot \mathrm{ml}^{-1}$ & Staphylococcus aureus & \\
\hline Sphingosine & $\mathrm{MIC}_{>50}=1.3-5.2 \mu \mathrm{g} \cdot \mathrm{ml}^{-1}$ & Corynebacterium strains & \\
\hline Phytosphingosine & $\mathrm{MIC}_{>50}=4.2-13 \mu \mathrm{g} \cdot \mathrm{ml}^{-1}$ & Corynebacterium strains & \\
\hline Sphinganine & $\mathrm{MIC}_{>50}=1-10.4 \mu \mathrm{g} \cdot \mathrm{ml}^{-1}$ & Corynebacterium strains & \\
\hline \multirow{3}{*}{$\begin{array}{l}\text { Haliscoamine (sphingosine } \\
\text { derivative) }\end{array}$} & $\mathrm{MIC}_{90}=0.2-0.4 \mu \mathrm{g} \cdot \mathrm{ml}^{-1}$ & Cryptococcus neoformans & \multirow{3}{*}{ El-Amraoui et al., 2013} \\
\hline & $\mathrm{MIC}_{90}=0.4-0.8 \mu \mathrm{g} \cdot \mathrm{ml}^{-1}$ & Candida ablicans & \\
\hline & $\mathrm{MIC}_{90}=0.4-0.8 \mu \mathrm{g} \cdot \mathrm{ml}^{-1}$ & Candida tropicalis & \\
\hline Ceramide & $100 \% \mathrm{MGI}$ at $100 \mu \mathrm{g} \cdot \mathrm{ml}^{-1}$ & Pythium aphanidermatum & \\
\hline Soya-Cerebroside I & $23 \%$ MGI at $100 \mu \mathrm{g} \cdot \mathrm{ml}^{-1}$ & Pythium aphanidermatum & \multirow{7}{*}{ Tang et al., 2010} \\
\hline Ceramide & $11 \% \mathrm{MGI}$ at $100 \mu \mathrm{g} \cdot \mathrm{ml}^{-1}$ & Fusarium oxysporum & \\
\hline Soya-Cerebroside I & $5 \% \mathrm{MGI}$ at $100 \mu \mathrm{g} \cdot \mathrm{ml}^{-1}$ & Fusarium oxysporum & \\
\hline Ceramide & $\mathrm{IC}_{50}=50.2 \mu \mathrm{g} \cdot \mathrm{ml}^{-1}$ & Bacillus subtilis & \\
\hline Soya-Cerebroside I & $\mathrm{IC}_{50}=110.9 \mu \mathrm{g} \cdot \mathrm{ml}^{-1}$ & Bacillus subtilis & \\
\hline Ceramide & $\mathrm{IC}_{50}=15.3 \mu \mathrm{g} \cdot \mathrm{ml}^{-1}$ & Pseudomonas lachrymans & \\
\hline Soya-Cerebroside I & $\mathrm{IC}_{50}=37.3 \mu \mathrm{g} \cdot \mathrm{ml}^{-1}$ & Pseudomonas lachrymans & \\
\hline Ficusamide (ceramide) & $\mathrm{MIC}=312.5 \mu \mathrm{g} \cdot \mathrm{ml}^{-1}$ & Escherichia coli & Dongfack et al., 2012 \\
\hline
\end{tabular}

Possemiers et al., 2005

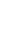

Possemiers et al. 2005 
Table 2 (continued). Antimicrobial activity of sphingolipids - L'activité antimicrobienne des sphingolipides.

\begin{tabular}{|c|c|c|c|}
\hline Sphingolipid & Inhibitory Concentration & Strain & Reference \\
\hline \multicolumn{4}{|l|}{ Growth inhibition } \\
\hline \multirow{3}{*}{$\begin{array}{l}\text { Lutaoside } \\
\text { (glucosylceramide) }\end{array}$} & $\mathrm{DIZ}=14 \mathrm{~mm}$ at $40 \mu \mathrm{g}$ pro $\mathrm{PD}$ & Chlorella vulgaris & \multirow{3}{*}{$\begin{array}{l}\text { Poumale Poumale } \\
\text { et al., } 2011\end{array}$} \\
\hline & $\mathrm{DIZ}=13 \mathrm{~mm}$ at $40 \mu \mathrm{g}$ pro $\mathrm{PD}$ & Chlorella sorokiniana & \\
\hline & $\mathrm{DIZ}=11 \mathrm{~mm}$ at $40 \mu \mathrm{g}$ pro PD & Scenedesmus subspicatus & \\
\hline $\begin{array}{l}\text { Penicilloside A } \\
\text { (cerebroside) }\end{array}$ & $\mathrm{GIZ}=23 \mathrm{~mm}$ at $100 \mu \mathrm{g}$ per cups $*$ & Candida ablicans & \multirow{3}{*}{$\begin{array}{l}\text { Murshid S.S.A. et al., } \\
2016\end{array}$} \\
\hline \multirow{2}{*}{$\begin{array}{l}\text { Penicilloside B } \\
\text { (cerebroside) }\end{array}$} & $\mathrm{GIZ}=19 \mathrm{~mm}$ at $100 \mu \mathrm{g}$ per cups $*$ & Staphylococcus aureus & \\
\hline & $\mathrm{GIZ}=20 \mathrm{~mm}$ at $100 \mu \mathrm{g}$ per cups $*$ & Escherichia coli & \\
\hline \multicolumn{4}{|l|}{ Adhesion inhibition } \\
\hline $\mathrm{G}_{\mathrm{M} 1}$ & $82.4 \%$ at $1 \mathrm{mg} \cdot \mathrm{ml}^{-1}$ & \multirow{5}{*}{ Escherichia coli } & \multirow{5}{*}{ Idota et al., 1995} \\
\hline $\mathrm{G}_{\mathrm{M} 3}$ & $68.6 \%$ at $1 \mathrm{mg} \cdot \mathrm{ml}^{-1}$ & & \\
\hline $\mathrm{G}_{\mathrm{D} 3}$ & $16.1 \%$ at $1 \mathrm{mg} \cdot \mathrm{ml}^{-1}$ & & \\
\hline Ceramide lactoside & $3.2 \%$ at $1 \mathrm{mg} \cdot \mathrm{ml}^{-1}$ & & \\
\hline $\mathrm{NeuAc}$ & No inhibition at $1 \mathrm{mg} \cdot \mathrm{ml}^{-1}$ & & \\
\hline $\mathrm{G}_{\mathrm{M} 1}$ & $\mathrm{IC}_{50}=>400 \mu \mathrm{M}$ & \multirow{3}{*}{ Helicobacter pylori } & \multirow{3}{*}{ Hata et al., 2004} \\
\hline $\mathrm{G}_{\mathrm{M} 3}$ & $\mathrm{IC}_{50}=379 \mu \mathrm{M}$ & & \\
\hline $\mathrm{G}_{\mathrm{D} 3}$ & $\mathrm{IC}_{50}=191 \mu \mathrm{M}$ & & \\
\hline
\end{tabular}

$\mathrm{MIC}_{>50}$ : Minimal Concentration causing inhibition higher than $50 \%$ - Concentration Minimale provoquant l'inhibition supérieure à $50 \%$; $\mathrm{MIC}_{90}$ : Minimal Concentration causing $90 \%$ inhibition - Concentration Minimale causant $90 \%$ d'inhibition; MGI:

Mycelia Growth Inhibition - Inhibition de la croissance du mycélium; DIZ: Diameter of Inhibition Zone - diamètre des zones d'inhibition; GIZ: Growth Inhibition Zone - diamètre des zones d'inhibition; PD: Paper Disk - Disque en papier; *: Agar Diffusion Method - Méthode de diffusion en gélose; > 400: binding inhibition fails to reach $50 \%$ at the dose of $400 \mu \mathrm{M}$ of inhibitor tested - l'inhibition de reliure ne parvient pas à atteindre $50 \%$ à la dose de $400 \mu \mathrm{M}$ d'inhibiteur testé.

cal activities (Shadyro et al., 2015). Phytosphingosine (4-hydroxysphinganine) can find applications towards skin healthcare. Phytosphingosine can be combined via an amide bond with salicylic acid (Farwick et al., 2007), for example in the presence of carbodiimide/hydroxybenzotriazole, as coupling reagents (Montalbetti et al., 2005). Such salicyloyl-phytosphingosine can become a promising agent for repair of photoaged skin (Farwick et al., 2007). N-acetyl sphingosine (commonly called C2-ceramide) is a product that originates from $N$-acylation of sphingosine, with acetic anhydride (Ohta et al., 1994). C2-ceramide was reported to induce apoptosis and exert anti-proliferative effect towards lung cancer cells (Lin et al., 2014). Sphingosine can also be $N$-acylated with p-nitrophenyl ester of disulfide linkage-containing fatty acid, resulting in the formation of $N$-dithiaheptanoyl ceramide. Such a compound showed increased anti-proliferative and cytotoxic activity against a number of cancer cell lines (Bittman et al., 2007). Galactocerebrosides can undergo galactofuranosylation, accompanied by partial acetylation, via a range of chemical modifications that lead to the synthesis of galactofuranosyl(triacetylgalactopyranosyl)acetylceramide. Such a synthetized com- pound could become a candidate for efficient delivery of orally administered glycosphingolipids to colon (Iga et al., 2008). Gangliosides $\left(\mathrm{G}_{\mathrm{MI}}\right)$ can be modified by methyl esterification of carboxyl group in sialic acid moiety. Methyl esters of $\mathrm{G}_{\mathrm{M} 1}$ ganglioside showed an increased reactivity with peanut agglutinin and decreased reactivity with Cholera toxin (Handa et al., 1984). Gangliosides can also undergo $O$-acetylation at C9 in a sialic acid unit via action of the enzyme, possessing $O$-acetyltransferase activity. Such acetylated glycosphingolipids are potential therapeutic drugs, against brain tumor development (Romero-Ramırez et al., 2012).

\section{CONCLUSIONS}

This review evaluates sphingolipids in terms of structure, availability in organic sources, extraction, purification and analysis methods, as well as their industrial applications. Various forms of sphingolipids can be found in numerous organic sources, available in the natural environment. In order to benefit from sphingolipids, an efficient extraction method should 
be harnessed, according to the source of sphingolipids. High performance analytical tools are indispensable to detect and characterize new sphingolipids structures. Sphingolipids seem to be promising candidates for application in food, cosmetic, pharmaceutical or medical industry. The potential of sphingolipid molecules will increase in the future, as new structures and new sources are regularly discovered. Moreover, the possibility of applying chemical methods to modify the structure of natural sphingolipids can further broaden their application field.

\section{Acknowledgements}

This work was financed by the CARE AgricultureIsLife, University of Liège-Gembloux Agro-Bio Tech, Belgium.

\section{Bibliography}

Alasil S.M., Omar R., Ismail S. \& \& Yusof M.Y., 2014. Antibiofilm activity, compound characterization, and acute toxicity of extract from a novel bacterial species of Paenibacillus. Int. J. Microbiol., Article ID 649420.

Alvarez J.G. \& Touchstone J.C., 1992. Separation of acidic and neutral lipids by aminopropyl-bonded silica gel column chromatography. J. Chromatogr., 577, 142-145.

Ando S. \& Yu R.K., 1979. Isolation and characterization of two isomers of brain tetrasialogangliosides. J. Biol. Chem., 254(23), 12224-12229.

Angstrom J. et al., 1981. Chemical characterization of penta-, hexa-, hepta-, octa-, and nonaglycosylceramides of rat small intestine having a globoside-like terminus. J. Biol. Chem., 257, 682-688.

Aoki K. et al., 2004. Newly discovered neutral glycosphingolipids in aureobasidin A-resistant zygomycetes: identification of a novel family of Galaseries glycolipids with core Gal alpha 1-6Gal beta 1-6Gal beta sequences. J. Biol. Chem., 279(31), 32028-32034.

Arakaki A. et al., 2013. Glycosylceramides from marine green microalga Tetraselmis sp. Phytochemistry, 85, 107-114.

Bibel D.J., Aly R. \& Shinefield H.R., 1992. Antimicrobial activity of sphingosines. J. Invest. Dermatol., 98(3), 269273.

Bieberich E., 2011. Ceramide in stem cell differentiation and embryo development: novel functions of a topological cell- signaling lipid and the concept of ceramide compartments. J. Lipids, Article ID 610306.

Bielawski J. et al., 2010. Sphingolipid analysis by High Performance Liquid Chromatography-Tandem Mass Spectrometry (HPLC-MS/MS). In: Chalfant Ch. \& Del Poeta M., eds. Sphingolipids as signaling and regulatory molecules. Landes Bioscience and Springer Science+Business Media, 46-59.

Bittman R., Li Z., Samadder P. \& Arthur G., 2007. Anticancer activity of a ceramide analog containing a disulfide linkage. Cancer Lett., 251, 53-58.
Bodennec J. et al., 2000. A procedure for fractionation of sphingolipid classes by solid-phase extraction on aminopropyl cartridges. J. Lipid Res., 41(9), 1524-1531.

Buré C., Cacas J.L., Mongrand S. \& Schmitter J.M., 2014. Characterization of glycosyl inositol phosphoryl ceramides from plants and fungi by mass spectrometry. Anal. Bioanal. Chem., 406(4), 995-1010.

Cacas J.-L. et al., 2012. Rapid nanoscale quantitative analysis of plant sphingolipid long-chain bases by GCMS. Anal. Bioanal. Chem., 403(9), 2745-2755.

Carter H.E. \& Gaver R.C., 1967. Improved reagent for trimethylsilylation of sphingolipid bases. J. Lipid Res., 8(4), 391-395.

Chan K. et al., 2009. MALDI mass spectrometry imaging of gangliosides in mouse brain using ionic liquid matrix. Anal. Chim. Acta, 639(1-2), 57-61.

Daniotti J.L. et al., 2013. Glycosylation of glycolipids in cancer: basis for development of novel therapeutic approaches. Front. Oncol., 3.

Devle H., Naess-Andresen C.F., Stenstrøm Y. \& Ekeberg D., 2011. Rapid method for analysis of sphingomyelin by microwave derivatisation for gas chromatography-mass spectrometry. Eur. J. Lipid Sci. Technol., 113(6), 708710 .

Dongfack M.D.J. et al., 2012. A new sphingolipid and furanocoumarins with antimicrobial activity from Ficus exasperata. Chem. Pharm. Bull., 60(8), 1072-1075.

Draelos Z.D., 2008. The effect of ceramide-containing skin care products on eczema resolution duration. Cutis, $\mathbf{8 1}$, 87-91.

Duk M. et al., 2007. Structures of unique globoside elongation products present in erythrocytes with a rare NOR phenotype. Glycobiology, 17(3), 304-312.

El-Amraoui B., Biard J.F. \& Fassouane A., 2013. Haliscosamine: a new antifungal sphingosine derivative from the Moroccan marine sponge Haliclona viscosa. SpringerPlus, 2, 252.

Farwanah H. et al., 2009. Normal phase liquid chromatography coupled to quadrupole time of flight atmospheric pressure chemical ionization mass spectrometry for separation, detection and mass spectrometric profiling of neutral sphingolipids and cholesterol. J. Chromatogr. B, 877, 2976-2982.

Farwick M. et al., 2007. Salicyloyl-phytosphingosine: a novel agent for the repair of photoaged skin. Int. J. Cosmet. Sci., 29(4), 319-329.

Fischer C.L. et al., 2012. Antibacterial activity of sphingoid bases and fatty acids against gram-positive and gramnegative bacteria. Antimicrob. Agents Chemother., 56, 1157-1161.

Fuchs B. et al., 2011. Lipid analysis by thin-layer chromatography - a review of the current state. J. Chromatogr. A, 1218, 2754-2774.

Gallier S. et al., 2010. Composition and fatty acid distribution of bovine milk phospholipids from processed milk product. J. Agric. Food Chem., 58(19), 10503-10511. 
Goretta S.A. et al., 2012. Effects of chemical modification of sphingomyelin ammonium group on formation of liquidordered phase. Bioorg. Med. Chem., 20(13), 4012-4019.

Goto H. et al., 2012. Determination of sphingoid bases from hydrolyzed glucosylceramide in rice and wheat by online post-column high-performance liquid chromatography with O-phthalaldehyde derivatization. J. Oleo Sci., 61(12), 681-688.

Groener J.E.M. et al., 2007. HPLC for simultaneous quantification of total ceramide, glucosylceramide, and ceramide trihexoside concentrations in plasma. Clin. Chem., 53(4), 742-747.

Gutierrez A.L.S. et al., 2007. Characterization of glycoinositolphosphoryl ceramide structure mutant strains of Cryptococcus neoformans. Glycobiology, 17(6), 1-11C.

Handa S. \& Nakamura K., 1984. Modification of sialic acid carboxyl group of ganglioside. J. Biochem., 95(5), 13231329.

Hata Y., Murakami M. \& Okabe S., 2004. Glycoconjugates with NeuAc-NeuAc-Gal-Glc are more effective at preventing adhesion of Helicobacter pylori to gastric epithelial cells than glycoconjugates with NeuAc-GalGlc. J. Physiol. Pharmacol., 55(3), 607-625.

Haynes C.A., Allegood J.C., Park H. \& Sullards M.C., 2009. Sphingolipidomics: methods for the comprehensive analysis of sphingolipids. J. Chromatogr. B, 877(26), 2696-2708.

Heung L.J., Luberto C. \& Del Poeta M., 2006. Role of sphingolipids in microbial pathogenesis. Infect. Immun., 74, 28-39.

Hidaka H., Takiwaki M. \& Yamashita M., 2012. Mild acid hydrolysis of sphingolipids yields lysosphingolipids: a matrix-assisted laser desorption and ionization time-offlight mass spectrometry study. J. Anal. Biosci., 35(3), 241-248.

Higuchi R. al., 2006. Biologically active glycosides from asteroidea, 42. Isolation and structure of a new biologically active ganglioside molecular species from the starfish Asterina pectinifera. Chem. Pharm. Bull., 54(3), 287-291.

Idota T. \& Kawakami H., 1995. Inhibitory effects of milk gangliosides on the adhesion of Escherichia coli to human intestinal carcinoma cells. Biosci. Biotechnol. Biochem., 59(1), 69-72.

Iga D.P. \& Iga S., 2008. Galactofuranosylated galactocerebrosides, a new drug delivery system for ceramides to colon. Open Org. Chem. J., 2, 46-51.

Imai H., Hattori H. \& Watanabe M., 2012. An improved method for analysis of glucosylceramide species having cis- 8 and trans- 8 isomers of sphingoid bases by LC-MS/ MS. Lipids, 47(12), 1221-1229.

Ishikawa T., Imai H. \& Maki K.Y., 2014. Development of an LC-MS/MS method for the analysis of free sphingoid bases using 4-fluoro-7-nitrobenzofurazan (NBD-F). Lipids, 49, 295-304.
Jeon S.-B. et al., 2008. Sulfatide, a major lipid component of myelin sheath, activates inflammatory responses as an endogenous stimulator in brain-resident immune cells. J. Immunol., 181(11), 8077-8087.

Jhon G.J. et al., 1999. Studies of the chemical structure of gangliosides in deer antler, Cervus nippon. Chem. Pharm. Bull., 47(1), 123-127.

Johnson S.B.\& Brown R.E., 1992. Simplified derivatization for determining sphingolipid fatty acyl composition by gas chromatography-mass spectrometry. J. Chromatogr., 605(2), 281-286.

Jungalwala F.B., Evans J.E., Bremer E. \& McCluer R.H., 1983. Analysis of sphingoid bases by reversed-phase high performance liquid chromatography. J. Lipid Res., 24(10), 1380-1388.

Kato T., Kasuya M.C.Z. \& Hatanaka K., 2008. Rapid separation of gangliosides using strong anion exchanger cartridges. J. Oleo Sci., 57(7), 397-400.

Khotimchenko S.V. \& Vaskovskii V.E., 2004. Inositolcontaining sphingolipid from red algae Gracilaria verrucosa. Bioorg. Khim., 30(2), 190-194.

Kim H.Y. \& Salem N. Jr., 1990. Separation of lipid classes by solid phase extraction. J. Lipid Res., 31, 22852289.

Kisa F. et al., 2006. Constituents of Holothuroidea, 17. Isolation and structure of biologically active monosialogangliosides from the sea Cucumber Cucumaria echinata. Chem. Pharm. Bull., 54(7), 982-987.

Kleuser B. \& Japtok L., 2013. Sphingolipids and inflammatory diseases of the skin. Handb. Exp. Pharmacol., 216, 355-372.

Kurek K. et al., 2013. Metabolism, physiological role, and clinical implications of sphingolipids in gastrointestinal tract. Biomed Res. Int., Article ID 908907.

Lee M.H., Lee G.H.\& Yoo J.S., 2003. Analysis of ceramides in cosmetics by reversed-phase liquid chromatography/ electrospray ionization mass spectrometry with collisioninduced dissociation. Rapid Commun. Mass Spectrom., 17, 64-75.

Lee S. et al., 2012. Quantitative analysis of sphingomyelin by high-performance liquid chromatography after enzymatic hydrolysis. Evidence-Based Complementary Altern. Med., 2012, e396218.

Lee Y.J. et al., 2012. Sphingolipid signaling mediates iron toxicity. Cell Metab., 16, 90-96.

Lin I.L. et al., 2014. The antiproliferative effect of C2ceramide on lung cancer cells through apoptosis by inhibiting Akt and NFkB. Cancer Cell Int., 14(1), doi: 10.1186/1475-2867-14-1.

Lynch D.V. \& Dunn T.M., 2004. An introduction to plant sphingolipids and a review of recent advances in understanding their metabolism and function. New Phytol., 161(3), 677-702.

Mahendran A. et al., 2015. Synthesis and antiproliferative properties of a new ceramide analog of varacin. Chem. Phys. Lipids, 194, 165-170. 
Maia A.I.V. et al., 2010. New ceramides from Acnistus arborescens. J. Braz. Chem. Soc., 21(5), 867-871.

Manirakiza P., Covaci A. \& Schepens P., 2001. Comparative study on total lipid determination using Soxhlet, Roese-Gottlieb, Bligh \& Dyer, and modified Bligh \& Dyer extraction methods. J. Food Compos. Anal., 14, 93-100.

Markham J.E., Li J., Cahoon E.B. \& Jaworski J.G., 2006. Separation and identification of major plant sphingolipid classes from leaves. J. Biol. Chem., 281(32), 2268422694.

Martínez-Beamonte R., Lou-Bonafonte J.M., MartínezGracia M.V. \& Osada J., 2013. Sphingomyelin in high-density lipoproteins: structural role and biological function. Int. J. Mol. Sci., 14, 7716-7741.

Maula T., Artetxe I., Grandell P.M. \& Slotte J.P., 2012. Importance of the sphingoid base length for the membrane properties of ceramides. Biophys. J., 103(9), 1870-1879.

Melo T. et al., 2012. Study of sphingolipids oxidation by ESI tandem MS. Eur. J. Lipid Sci. Technol., 114, 726732.

Montalbetti C.A.G.N. \& Falque V., 2005. Amide bond formation and peptide coupling. Tetrahedron, 61(46), 10827-10852.

Mroczynska M.,LibudziszZ.,Gałęcka M.\& Szachta P.,2011. Mikroorganizmy jelitowe człowieka i ich aktywnosc metaboliczna. Przeglad Gastroenterologiczny, 6(4), 218-224.

Murshid S.S.A., Badr J.M. \& Youssef D.T.A., 2016. Penicillosides A and B: new cerebrosides from the marine-derived fungus Penicillum species. Rev. Bras. Farmacognosia, 26, 29-33.

Naka T. et al., 2003. Structural analysis of sphingophospholipids derived from Sphingobacterium spiritivorum, the type species of genus Sphingobacterium. Biochim. Biophys. Acta, 1635, 83-92.

O'Brien J.S. \& Rouser G., 1964. The fatty acid composition of brain sphingolipids: sphingomyelin, ceramide, cerebroside, and cerebroside sulfate. J. Lipid Res., 5(3), 339-342.

Ogiso H. et al., 2014. Comparative analysis of biological sphingolipids with glycerophospholipids and diacylglycerol by LC-MS/MS. Metabolites, 4(1), 98114.

Ohta H., Ruan F., Hakomori S. \& Igarashi Y., 1994. Quantification of free sphingosine in cultured cells by acylation with radioactive acetic anhydride. Anal. Biochem., 222(2), 489-494.

Possemiers S., Van Camp J., Bolca S. \& Verstraete W., 2005. Characterization of the bactericidal effect of dietary sphingosine and its activity under intestinal conditions. Int. J. Food Microbiol., 105(1), 59-70.

Poumale Poumale H.M. et al., 2011. A new ceramide isolated from Ficus lutea Vahl (Moraceae). Acta Chim. Slov., 58, 81-86.
Ramírez R. et al., 2008. Supercritical fluid extraction to obtain ceramides from wool fibers. Sep. Purif. Technol., 63(3), 552-557.

Rho J.R. \& Kim Y.H., 2005. Isolation and structure determination of three new ceramides from the starfish Distolasterias nipon. Bull. Korean Chem. Soc., 26(9), 1457-1460.

Rodriguez P.E., Maggio B. \& Cumar F.A., 1996. Acid and enzymatic hydrolysis of the internal sialic acid residue in native and chemically modified ganglioside GM1. J. Lipid Res., 37(2), 382-390.

Romero-Ramirez L. et al., 2012. Specific synthesis of neurostatin and gangliosides $\mathrm{O}$-acetylated in the outer sialic acids using a sialate transferase. PLOS ONE, 7(12), e49983.

Salcedo J., 2013. Gangliosides and sialic acid effects upon newborn pathogenic bacteria adhesion: an in vitro study. Food Chem., 136, 726-734.

Sambanthamoorthy K. et al., 2014. Antimicrobial and antibiofilm potential of biosurfactants isolated from lactobacilli against multi-drug-resistant pathogens. BMC Microbiol., 14, 197.

Sandbhor M.S., Key J.A., Strelkov I.S. \& Cairo C.W., 2009. A modular synthesis of alkynyl-phosphocholine headgroups for labeling sphingomyelin and phosphatidylcholine. J. Org. Chem., 74(22), 8669-8674.

Schneider-Schaulies J. \& Schneider-Schaulies S., 2013. Viral infections and sphingolipids. Handb. Exp. Pharmacol., 216, 321-340.

Shadyro O. et al., 2015. Free-radical destruction of sphingolipids resulting in 2-hexadecenal formation. Lipid Insights, 8, 1-9, doi:10.4137/Lpi.s24081.

Shaner R.L. et al., 2009. Quantitative analysis of sphingolipids for lipidomics using triple quadrupole and quadrupole linear ion trap mass spectrometers. J. Lipid Res., 50, 1692-1707.

Shiraishi T. \& Uda Y., 1985. Characterization of neutral sphingolipids from chicken erythrocytes. J. Lipid Res., 26(7), 860-866

Sisu E. et al., 2011. High-performance separation techniques hyphenated to mass spectrometry for ganglioside analysis. Electrophoresis, 32(13), 1591-1609.

Skrzypek M.S., Nagiec M.M., Lester R.L. \& Dickson R.C., 1999. Analysis of phosphorylated sphingolipid longchain bases reveals potential roles in heat stress and growth control in Saccharomyces. J. Bacteriol., 181, 1134-1140.

Smirnova G.P., Glukhoded I.S. \& Kochetkov N.K., 1988. A branched disialoganglioside containing $\mathrm{N}$-acetylgalactosamine from the starfish Asterias rubens. Russ. J. Bioorg. Chem., 14(5), 636-641.

Sonnenburg J.L., van Halbeek H. \& Varki A., 2002. Characterization of the acid stability of glycosidically linked neuraminic acid: use in detecting de- $N$-acetylgangliosides in human melanoma. J. Biol. Chem., 277(20), 17502-17510. 
Spiegel S.\& Merrill Jr.A.H., 1996. Sphingolipid metabolism and cell growth regulation. FASEB J., 10, 1388-1397.

Sugita M., Dulaney J.T. \& Moser H.W., 1974. Structure and composition of sulfatides isolated from livers of patients with metachromatic leukodystrophy: galactosyl sulfatide and lactosyl sulfatide. J. Lipid Res., 15(3), 227-233.

Tadano-Aritomi K.etal., 1998. Isolation and characterization of a unique sulfated ganglioside, sulfated GM1a, from rat kidney. Glycobiology, 8(4), 341-350.

Tanaka I., Matsuoka S., Murata M. \& Tachibana K., 1998. A new ceramide with a novel branched-chain fatty acid isolated from the epiphytic dinoflagellate Coolia monotis. J. Nat. Prod., 61(5), 685-688.

Tang J. et al., 2010. Antimicrobial activity of sphingolipids isolated from the stems of cucumber (Cucumis sativus L.). Molecules, 15(12), 9288-9297.

Tao R.V., $\quad$ Sweeley C.C. \& Jamieson G.A., 1973. Sphingolipid composition of human platelets. J. Lipid Res., 14(1), 16-25.

Tidhar R. \& Futerman A.H., 2013. The complexity of sphingolipid biosynthesis in the endoplasmic reticulum. Biochim. Biophys. Acta, 1833, 2511-2518.

Tirodkar T.S. \& Voelkel-Johnson C., 2012. Sphingolipids in apoptosis. Exp. Oncol., 34, 231-242.

Vesper H. et al., 1999. Sphingolipids in food and the emerging importance of sphingolipids to nutrition. J. Nutr., 129, 1239-1250.

Watanabe M. \& Imai H., 2011. Characterization of glucosylceramides in leaves of the grass family (Poaceae): Pooideae has unsaturated hydroxy fatty acids. Biosci. Biotechnol. Biochem., 75(9), 1838-1841.

Wertz P.W. \& Downing D.T., 1983. Ceramides of pig epidermis: structure determination. J. Lipid Res., 24(6), 759-765.
Whalen M.M., Wild G.C., Spall W.D. \& Sebring R.J., 1986. Separation of underivatized gangliosides by ion exchange high performance liquid chromatography. Lipids, 21(4), 267-270.

Xu K. \& Thornalley P.J., 2000. Antitumour activity of sphingoid base adducts of phenethyl isothiocyanate. Bioorg. Med. Chem. Lett., 10(1), 53-54.

Yamada K. et al., 2008. Isolation and structure of a monomethylated ganglioside possessing neuritogenic activity from the ovary of the sea urchin Diadema setosum. Chem. Pharm. Bull., 56(5), 734-737.

Youssef D.T.A. et al., 2016. New cerebroside and nucleoside derivatives from a red sea strain of the marine cyanobacterium Moorea producens. Molecules, 21, 324.

Zanetta J.P. et al., 2001. Diversity of sialic acids revealed using gas chromatography/mass spectrometry of heptafluorobutyrate derivatives. Glycobiology, 11(8), 663-676.

Zhao F. et al., 2013. Structural elucidation of two types of novel glycosphingolipids in three strains of Skeletonema by liquid chromatography coupled with mass spectrometry. Rapid Commun. Mass Spectrom., 27, 1535-1547.

Zhou B. et al., 1989. Isolation and characterization of ceramide glycanase from the leech, Macrobdella decora. J. Biol. Chem., 264(21), 12272-12277.

Zhou L. et al., 2012. Liquid chromatography-tandem mass spectrometry for the determination of sphingomyelin species from calf brain, ox liver, egg yolk, and krill oil. J. Agric. Food Chem., 60, 293-298.

Zwir-Ferenc A. \& Biziuk M., 2006. Solid phase extraction technique-trends, opportunities and applications. Polish J. Environ. Stud., 15(5), 677-690.

(106 ref.) 